\title{
Coronary artery disease in patients after orthotopic heart transplantation treated with percutaneous coronary intervention - a single centre's experience
}

Choroba tętnic wieńcowych u chorych po transplantacji leczona metodą przezskórnej angioplastyki wieńcowej - doświadczenia pojedynczego ośrodka

\author{
Małgorzata Sobieszczańska-Małek ${ }^{1}$, Tomasz Zieliński ${ }^{1}$, Maciej Karcz², Małgorzata Piotrowska', \\ Łukasz Kalińczuk³ ${ }^{3}$ Krzysztof Komuda', Paweł Bekta², Adam Witkowski², Witold Rużyłło², Jerzy Korewicki ${ }^{1}$
}

1Department of Heart Failure and Transplantology, Institute of Cardiology, Warsaw, Poland

2Department of Interventional Cardiology and Angiology, Institute of Cardiology, Warsaw, Poland

${ }^{3}$ Department of Coronary Artery Disease and Structural Heart Diseases, Institute of Cardiology, Warsaw, Poland

Post Kardiol Interw 2010; 6, 4 (22): 161-166 DOI: $10.5114 /$ pwki.2010.17629

\begin{abstract}
Background: Some patients after orthotopic heart transplantation (OHT) develop coronary focal lesions and may need interventional therapy.

Aim: To determine the frequency and time course of narrowing of epicardial coronary arteries in transplanted hearts, potential risk factors and results of percutaneous coronary interventions.

Methods and results: Demographic and coronary angiography data of 265 patients after OHT, mean age 53.0 \pm 14.6 , were analysed Significant focal narrowing of the coronary artery was diagnosed when there was a decrease of $50 \%$ or more of the lumen of the coronary artery. Mean time from OHT to the end of observation was $6.2 \pm 4.5$ (range 0.5 - 23 ) years. Thirty-six (14\%) patients after OHT had significant focal changes in coronary arteries. In 16 patients the degree of stenosis, lesion, location or calibre of the vessel was not suitable for interventional therapy. Twenty (55\%; 18 men) patients underwent coronary intervention. Mean age of patients during coronary intervention was $53.5 \pm 9.8$ years and of those without intervention at the end of observation was $52.5 \pm 14.9$ years (NS) In patients with intervention mean time from $\mathrm{OHT}$ to intervention was $7.0 \pm 4.6$ years. In patients with coronary intervention mean time from OHT to the end of observation was $10.8 \pm 6.5$ years and in patients without intervention $5.8 \pm 4.1$ ( $p<0.001)$. Analysis of Kaplan-Meier curves showed that probability of coronary stenosis-free survival diminishes rapidly after 5 years following OHT. Patients who required coronary intervention had significantly higher hsCRP as compared to those without intervention (0.720 vs. 0.044 , $p=0.025$ ). There were no statistical differences between the two groups in cholesterol level, BMI or incidence of diabetes, number of acute cellular episodes or Quilty effect.

Conclusions: Significant focal coronary stenoses are found mainly more than 5 years post heart transplantation. Most patients can be treated safely and effectively with percutaneous coronary intervention with contrast-induced nephropathy prophylaxis. Risk factors of coronary vasculopathy post OHT require further investigations.
\end{abstract}

Key words: vasculopathy, heart transplantation, coronary artery disease, percutaneous coronary intervention

\section{Streszczenie}

Wstęp: U pacjentów po transplantacji serca (OHT) mogą się rozwijać zmiany w naczyniach wieńcowych, które niejednokrotnie wymagają leczenia interwencyjnego.

Cel: Ocena przebiegu zmian w naczyniach wieńcowych, potencjalnych czynników ryzyka oraz wyników leczenia przezskórną angioplastyką wieńcową.

Metody i wyniki: Analizie poddano badania koronarograficzne 265 pacjentów w wieku średnio 53,0 $\pm 14,6$ roku. Za istotne zmiany w naczyniach wieńcowych przyjęto zwężenie światła naczynia powyżej 50\%. Interwencję (angioplastykę) wykonywano przy zwężeniu powyżej 70\%. W przypadkach pośrednich wykonywano ultrasonograficzną ocenę światła naczyń wieńcowych. Średni czas od

Corresponding author/Adres do korespondencji:

Małgorzata Sobieszczańska-Małek MD, PhD, Klinika Niewydolności Serca i Transplantologii, Instytut Kardiologii, ul. Alpejska 42, 04-628 Warszawa, tel.: +48223434483, e-mail: m.sobieszczanska@ikard.pl

Praca wpłynęła 30.05.2010, wersja poprawiona 7.11.2010, przyjęta do druku 10.11.2010. 
przeszczepu do zakończenia obserwacji wynosił 6,2 $\pm 4,5$ roku (zakres 0,5-23). Trzydziestu sześciu (14\%) pacjentów po OHT miało istotne zmiany w nasierdziowych tętnicach wieńcowych. U 16 pacjentów ze względu na stopień zwężenia, lokalizację zmian czy kaliber naczynia nie podejmowano interwencji. Dwudziestu pacjentów (55\%; 18 mężczyzn) miało wykonaną angioplastykę. Średni wiek pacjentów w tej grupie wynosił 53,5 $\pm 9,8$ roku, a w grupie bez interwencji 52,5 $\pm 14,9$ roku (NS). W grupie pacjentów z interwencją średni czas od OHT do interwencji wynosił 7,0 $\pm 4,6$ roku. U pacjentów poddanych zabiegowi średni czas od OHT do zakończenia obserwacji wyniósł 10,8 $\pm 6,5$ roku, a u pacjentów bez zabiegu 5,8 $\pm 4,1$ roku $(p<0,001)$. Analizując krzywe Kaplana-Meiera stwierdzono, że prawdopodobieństwo niewystępowania zmian w tętnicach wieńcowych szybko maleje powyżej 5 lat po transplantacji. Grupa, w której u chorych podjęto interwencję w naczyniach wieńcowych, miała istotnie wyższe hsCRP $(0,720$ vs 0,044, p=0,025). Nie stwierdzono istotnych statystycznie różnic między obiema grupami w zakresie stężeń cholesterolu, BMI, występowania cukrzycy czy liczby epizodów ostrego odrzucania komórkowego lub występowania efektu Quilty.

Wnioski: Istotne zlokalizowane zwężenia w tętnicach wieńcowych stwierdza się głównie powyżej 5 lat od przeszczepienia serca. Większość takich pacjentów można bezpiecznie i skutecznie leczyć przezskórną interwencją wieńcową z uwzględnieniem profilaktyki nefropatii pokontrastowej. Czynniki ryzyka waskulopatii tętnic wieńcowych po przeszczepieniu serca wymagają dalszych badań.

Słowa kluczowe: waskulopatia, transplantacja serca, choroba wieńcowa, angioplastyka wieńcowa

\section{Introduction}

Patients after orthotopic heart transplantation $(\mathrm{OHT})$ are not free of coronary vascular disease. The development of vascular changes in coronary vessels after heart transplantation is multifactorial. There are strong suggestions that the initial event - chronic graft rejection - starts in the very first months after heart transplantation. And this process continues during the life of the graft. There are data indicating that in the $5^{\text {th }}$ year post heart transplantation vascular changes are present in $25-60 \%$ of patients [1, 2]. According to data from the International Society of Heart and Lung Transplantation (ISHLT) registry coronary artery disease is the cause of death of $7.8 \%$ of patients after one year, of $30.8 \%$ after five years and $51.9 \%$ after 10 years post heart transplantation [3]. Vascular changes in the heart which are a leading cause of death after 10 years post heart transplantation are complex. Already early after heart transplantation there is an

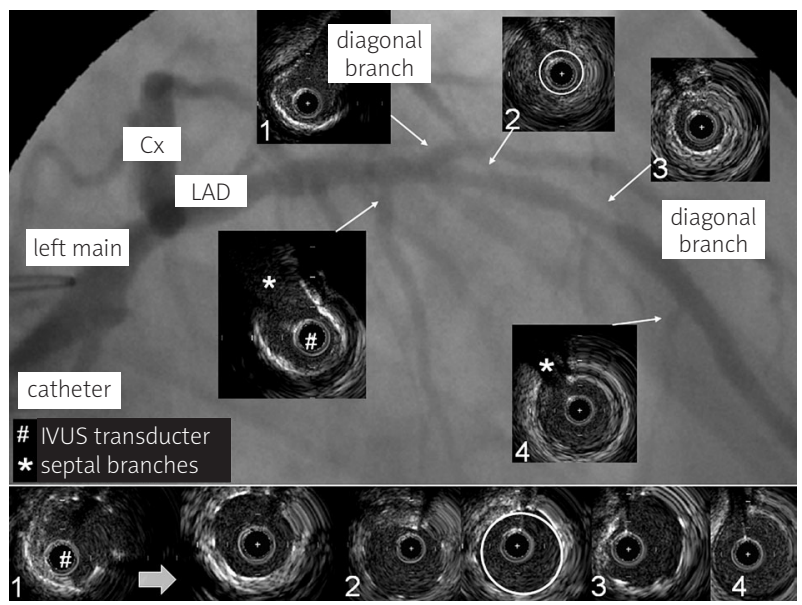

Fig. 1. Focal and intima media changes in transplant vasculopathy (IVUS)

$\mathrm{CX}$ - circumflex artery, LAD - left artery descending

Ryc. 1. Zmiany ogniskowe oraz zmiany kompleksu intima-media w waskulopatii serca przeszczepionego (obraz IVUS)

$C x$ - gatąż okalająca, LAD - gataź przednia zstępująca increase of the intima media thickness of the coronaries. Thickening of the intima media leads to a progressive multifocal localized or diffuse narrowing of the lumen of coronary arteries (fig. 1.) which can result in coronary insufficiency. Vascular changes in the vessels are not limited to the coronary arteries of different diameter but also can be found in the coronary venous system. There is no definite explanation of this special pattern of vascular disease called graft vasculopathy, although endothelial dysfunction of the graft vascular system is often suspected to be the initial event [4].

Early development of vascular changes, within 2 years after $\mathrm{OHT}$, is related to the presence of episodes of acute cellular rejection [5]. Changes which occur later can be stimulated by cytomegalovirus (CMV) infections, lipid disorders and other classical risk factors. Factors leading to the development of vascular disease of the graft can be alloantigen dependent or alloantigen independent. Alloantigen-dependent factors are: the number of HLA mismatches, and the number and time course of episodes of acute cellular rejection [6].

Among alloantigen-independent factors probably the most important are classic atherosclerotic risk factors such as lipid disorders, obesity, smoking, hypertension, diabetes, and hyperhomocysteinaemia. Other factors are more specific for immunocompromised patients, such as CMV infection, which stimulates cytokine (TNF- $\alpha$ ) and interleukin (IL1, IL-4, IL-6) production, also changing lipid metabolism and stimulating thrombus formation [7], related to the procedure such as ischaemia reperfusion injury or related to the donor such as older age or brain death of the donor. During the early postoperative period due to ischaemia reperfusion injury of the transplanted heart a significant injury to the endothelial cells occurs, which promotes inflammatory processes with increased adhesion of platelets, and increased expression of MHC complexes I and II and adhesion molecules to endothelial cells, initiating smooth muscle cell proliferation. In the media and adventitia arterial layers cellular infiltration composed of lymphocytes, macrophages and modified smooth muscle cells can be found on histological examination [8]. 
Simultaneously there is a continuous immunological response stimulated by HLA antigens present at the endothelial surface. T lymphocytes, especially from CD4 line with MHC antigens class II, play an important role in this reaction. With a strong reaction to endothelial antigens an acute graft rejection reaction occurs. But even a weaker reaction can stimulate activation of the endothelial cells and increase the expression of adhesion molecules, and tissue activated clotting factor. Endothelial cells produce biologically active molecules such as platelet-derived growth factor (PDGF), platelet-activating factor (PAF), and tumour necrosis factor (TNF). When these molecules are present on the surface of endothelial cells they facilitate the migration of circulating macrophages, $T$ lymphocytes and granulocytes to the graft. These cells are the source of cytokines and growth factors stimulating smooth muscle cells. An additional effect is a change of the phenotype of myocytes from contractile to endocrine (fetal) type. The next steps are similar to those in classical atherosclerotic plaque formation, leading to a decrease of contracting elements of the arterial wall. Myocytes and fibroblasts migrate to the media layer as well as macrophages loaded with lipids. During this slow process proliferative changes prevail over degenerative ones, leading to an increase of intima media thickness [9].

Alloantigen-dependent mechanisms seem to be especially important due to the fact that in heart transplantation no prospective HLA matching is used. Because of this in heart transplant recipients there is an important risk of circulating anti-HLA antibodies, which can initiate that reaction.

Heart transplantation results in heart denervation, which can obscure ischaemic symptoms and make the diagnosis of coronary insufficiency particularly difficult. For that reason and due to the considerable incidence of progressive vasculopathy in transplanted hearts, routine repeated coronary angiography is performed in heart transplant recipients in the majority of heart transplant care centres. Some early atheromatic changes in coronary arteries may already be present in the donor heart, especially when hearts from older or marginal donors are transplanted. An early (donor heart) coronary angiography can detect those cases early.

The aim of the study was to determine the frequency and time course of narrowing of epicardial coronary arteries in transplanted hearts which can be treated with interventional procedures.

\section{Material and methods}

We analysed data of patients after OHT performed between 1987 and 2009 and followed up in the Department of Heart Failure and Transplantation of the Institute of Cardiology on a regular schedule. In order to detect coronary artery disease patients had their first coronary angiogram done 12 months post OHT or earlier if clinically necessary, and preferably at least every 24 months thereafter. If coronary lesions were detected, an angiographic study was repeated every year. Femoral access was usually used. Significant focal narrowing of the coronary artery was diagnosed when there was a decrease of $50 \%$ or more of the diameter of the coronary artery. Patients with $70 \%$ or greater stenosis with a favourable anatomy were considered for interventional therapy. In some cases when borderline changes in the range of 50$70 \%$ with focal narrowing and favourable anatomy were found their significance was verified by intravascular ultrasound (IVUS).

Number of patients, number of arteries with significant focal changes in angiogram, number of interventions, type of stent used (bare metal stent [BMS] or drug-eluting stent [DES]) and time to detection of significant focal coronary stenoses or time to intervention after $\mathrm{OHT}$ were analysed. Baseline (pre-angiography) renal function (creatine level, eGFR) was assessed. To prevent contrast-induced nephropathy patients were given $600 \mathrm{mg}$ acetylcysteine $12 \mathrm{~h}$ before examination and $500 \mathrm{ml} 0.9 \% \mathrm{NaCl}$. When urgent coronary angiography was needed, the acetylcysteine dose was doubled. This was administered for $48 \mathrm{~h}$ and serum creatinine, eGFR, and potassium were checked again $48 \mathrm{~h}$ and $72 \mathrm{~h}$ post procedure [10]. According to our protocol scheduled angiography was performed at the time of myocardial biopsy according to ISHLT criteria [11].

An immunosuppressive triple drug therapy protocol was used consisting of calcineurin inhibitor (cyclosporine or tacrolimus), an antiproliferative drug (azathioprine until year 2002 and mycophenolate mofetil thereafter) and steroid (prednisone, which was withdrawn 12 months post $\mathrm{OHT}$ ). As standard therapy all patients after OHT received among other drugs acetylsalicylic acid and statins in doses adapted to tolerance (interaction with immunosuppressive drugs) and lipid profile. Patients after an interventional procedure were treated with acetylsalicylic acid and ticlopidine or, from year 2005, with clopidogrel 75 mg/day according to guidelines.

\section{Statistical analysis}

Continuous data were expressed as mean and standard deviation, categorical data as percentages. Demographic characteristics were compared between groups using Student's unpaired $t$ tests. Categorical variables were compared using chi square tests. We used Kaplan-Meier survival analyses to estimate time to the detection of significant focal narrowing of coronary arteries or survival free from coronary intervention. Observations in KaplanMeier analyses were censored at death or the end of follow-up. All analyses were performed using the Statistica 7.1 (StatSoft. Inc. USA, 2005) package.

\section{Results}

There were 265 patients after OHT (217 men, mean age $53.0 \pm 14.6$ years). Mean time from OHT to the end of 
follow-up was $6.2 \pm 4.5$ (range 0.5 -23) years. Significant focal stenoses in coronary arteries were found in 36 patients (14\%). In 16 patients the degree of stenosis, lesion location or vessel diameter was not suitable for interventional therapy. Twenty patients ( $55 \%$ of those with focal stenoses; 18 men) underwent coronary intervention. In those 20 patients significant stenoses of 37 arteries were diagnosed. Stents were implanted in 23 vessels (mean 1.15 vessel, range 1 to 2 vessels per patient). Fifteen (65\%) were drug-eluting stents and 8 (35\%) bare metal stents. Thirteen stents were placed in the right coronary artery, 7 stents in the left descending artery, and 1 each in the circumflex, diagonal, and marginal artery. Mean stent diameter was $3.3 \pm 0.7 \mathrm{~mm}$ and mean length was 16.2 $\pm 5.3 \mathrm{~mm}$. Most stents (65\%) were deployed using the direct technique under high pressure (13.9 \pm 2.9 atmospheres).

In the group with intervention mean age at the time of heart transplantation was $47.5 \pm 10.2$ years and in the group without intervention it was $46.7 \pm 14.0$ years (NS). Mean age of patients during coronary intervention was $53.5 \pm 9.8$ years and of those without intervention at the end of follow-up it was $52.5 \pm 14.9$ years (NS). In patients with intervention mean time from $\mathrm{OHT}$ to intervention was $7.0 \pm 4.6$ years. In patients with coronary intervention mean time from OHT to the end of follow-up was 10.8 \pm 6.5 years and in patients without intervention it was 5.8 $\pm 4.1(p<0.001)$.

In 16 patients $\mathrm{PCl}$ was scheduled after 7 days on ticlopidine (500 mg daily) or clopidogrel (75 mg daily)

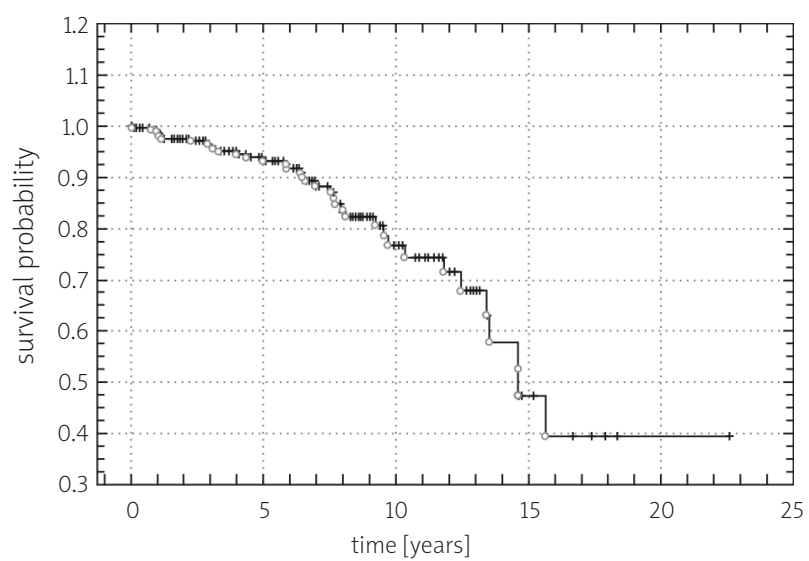

- complete + censored

Fig. 2. Kaplan-Meier curves; probability of eventfree survival after OHT (without significant narrowing of coronary arteries). Complete: at least $50 \%$ stenosis of coronary artery. Censored: death or end of follow-up

Ryc. 2. Krzywe Kaplana-Meiera. Prawdopodobieństwo przeżycia bez zmian w tętnicach wieńcowych po transplantacji serca. Zdarzenie: co najmniej 50-procentowe zwężenie w tętnicy wieńcowej. Obserwacje przerwane: śmierć lub koniec obserwacji following diagnostic coronary angiography and in 4 patients ad hoc PCl was performed following a loading dose of 300 mg clopidogrel. Femoral access was used in most cases (including one case where a 4-year-old vascular prosthesis was punctured) and radial access was used in 2 cases. After treatment 2 patients had a false aneurysm and 1 patient had an arterio-venous fistula, all treated conservatively. No complications attributable to contrast administration were noted. Mean creatinine level was $134.53 \mu \mathrm{mol} / /$ (eGFR $61.17 \mathrm{ml} / \mathrm{min} / 1.73 \mathrm{~m}^{2}$ ) before angiography and $135.1 \mu \mathrm{mol} / \mathrm{l}\left(\mathrm{eGFR} 59.31 \mathrm{ml} / \mathrm{min} / 1.73 \mathrm{~m}^{2}\right.$ ) after stent implantation (NS). One patient with critical kidney failure (on the waiting list for kidney transplantation) had angiography between haemodialysis procedures. There were no procedure-related deaths or myocardial infarctions. Two patients from the intervention group died during follow-up. Two cases of restenosis were noted, both in BMS implanted in the right coronary artery; they occurred 6 and 10 years post implantation.

The Kaplan-Meier curve designed to analyse survival free from significant focal stenoses in coronary arteries (fig. 2) is flat up to 5 years and becomes steeper after that time, showing an increase of risk between 5 and 10 years after OHT. The same tendency is observed in the KaplanMeier curve depicting intervention-free survival (fig. 3).

HsCRP level was significantly higher in the intervention group ( 0.720 vs. $0.044 \mathrm{mg} / \mathrm{dl}, p=0.025$ ) (table 1 ). There were no statistical differences between groups in cholesterol level $(4.44 \mathrm{mmol} / \mathrm{l}$ in the group without intervention vs.

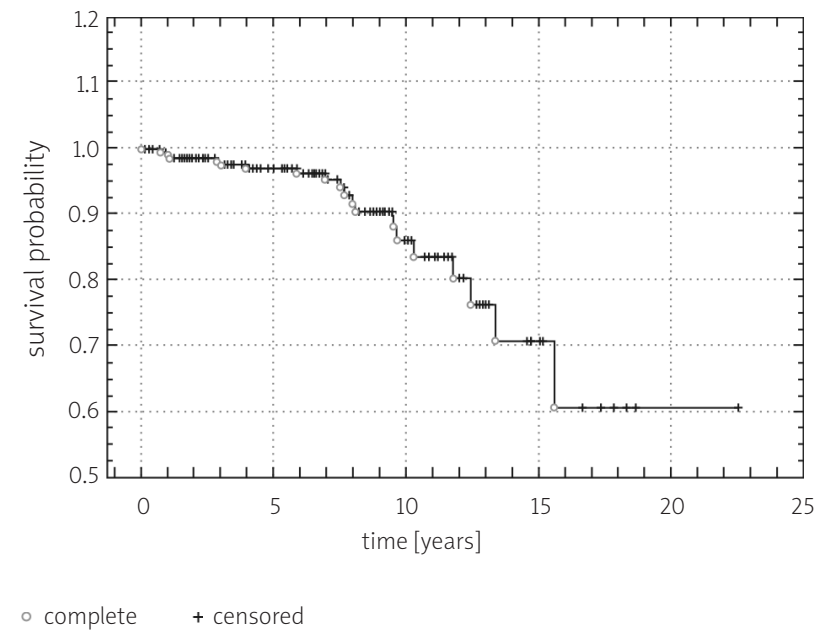

Fig. 3. Kaplan-Meier curves: probability of eventfree survival after OHT (without coronary intervention). Complete: coronary intervention. Censored: death or end of follow-up

Ryc. 3. Krzywe Kaplana-Meiera. Prawdopodobieństwo przeżycia bez interwencji na naczyniach wieńcowych. Zdarzenie: angioplastyka wieńcowa. Obserwacje przerwane: śmierć lub koniec obserwacji 
Table 1. Potential risk factors in patients with and without coronary intervention

Tabela 1. Potencjalne czynniki ryzyka w grupie pacjentów z interwencją i bez interwencji

\begin{tabular}{lccc} 
& $\begin{array}{c}\text { Group with } \\
\text { intervention }\end{array}$ & $\begin{array}{c}\text { Group without } \\
\text { intervention }\end{array}$ & $p$ \\
\hline Age at the time of OHT & $45.6 \pm 13.8$ & $46.9 \pm 13.8$ & NS \\
\hline Hypertension [\%] & 65 & 60 & NS \\
\hline Smokers [\%] & 29 & 20 & NS \\
\hline Diabetes [\%] & 23 & 20 & NS \\
\hline CMV & $33 \%$ & $25 \%$ & NS \\
\hline Cholesterol [mmol/l] & $4.44 \pm 1.14$ & $4.44 \pm 0.99$ & NS \\
\hline hsCRP [mg/dl] & $0.72 \pm 0.7$ & $0.44 \pm 0.48$ & 0.025
\end{tabular}

$4.43 \mathrm{mmol} / \mathrm{l}$ in the intervention group), body mass index (BMI) $\left(25.8 \mathrm{vs} .25 .5 \mathrm{~kg} / \mathrm{m}^{2}\right)$ or incidence of diabetes. There were also no statistical differences in number of acute cellular episodes (ACR) or Quilty effect.

\section{Discussion}

The incidence of vascular coronary disease found in our study is lower than in many published reports analysing vasculopathy of the transplanted heart. However, in keeping with the methodology based on coronary angiography only focal stenoses tighter than $50 \%$ which were potentially amenable with coronary intervention were analysed That may explain this relatively low incidence of coronary lesions.

In our patients the mean time between heart transplantation and intervention was 7 years. Such a time span between heart transplantation and coronary intervention is characteristic of atheroma-like coronary lesions according to Bilingham [12].

Twenty stents were implanted: 12 DES and 8 BMS according to clinical conditions and local policy. The risk of restenosis is perceived to be usually higher in patients after heart transplantation than in the native heart [13]. Aquel et al., Tanaka et al., and Lekston et al. demonstrated that DES implantation results in lower risk of restenosis as compared to BMS [14-16]. We were not able to confirm that finding, probably due to the relatively small number of patients with only 2 incidents of restenosis.

We observed incidentally rapid progression of coronary lesions in some patients (fig. 4). Patients in the intervention group had a higher level of hsCRP. This may suggest an immunological background of accelerated atherosclerosis in this group. There were no significant differences between the two groups in cholesterol level or BMI. In our study we have not confirmed a correlation between Quilty effect (endocardial infiltration of lymphocytes) and atherosclerosis. In published studies the significance of the Quilty effect was not proved either [17, 18].

No important complications related to $\mathrm{PCl}$ procedures were observed including 4 ad hoc cases. Contrast-induced

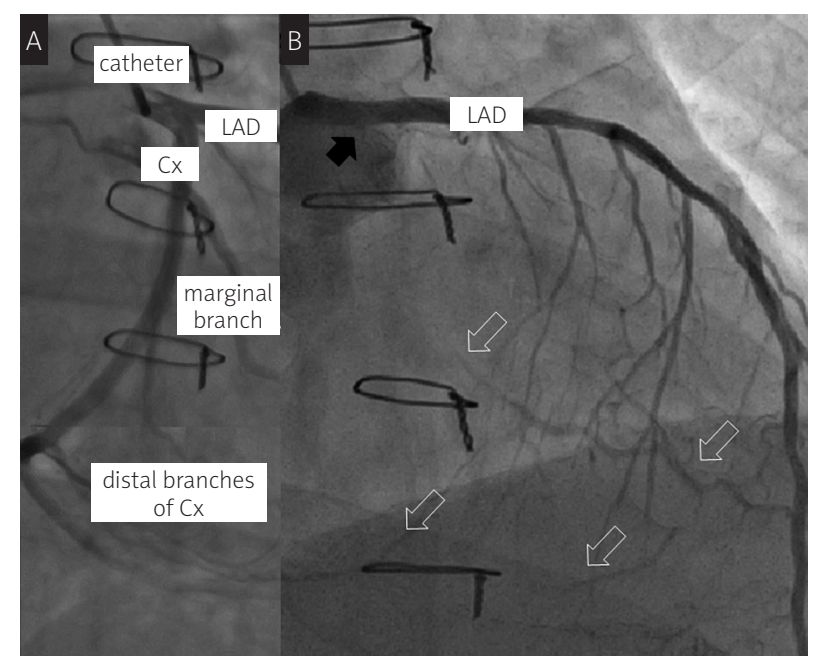

Fig. 4. Two coronary angiograms of the same patient performed one year apart ( $\mathrm{B}$ - one year later, 31-year-old woman, 10 years after OHT) $C x$ - circumflex artery, LAD - left artery descending, black arrow proximal occlusion of $\mathrm{Cx}$, empty arrows - distal branches of $\mathrm{Cx}$ filling by collateral circulation from $L A D$

Ryc. 4. Dwie koronarografie wykonane w odstępie jednego roku (B - 1 rok później, pacjentka 31-letnia, 10 lat po transplantacji serca)

Cx - gałaź okalająca, LAD - gałaź przednia zstępujaca, czarna strzatka-proksymalna niedrożność CX, puste strzatki-gatęzie obwodowe CX wypetniające się przez krążenie oboczne od LAD

nephropathy was not noted. According to the protocol used in our centre every patient was given acetylcysteine and normal saline i.v. prior to contrast administration.

\section{Limitations of the study}

This is a retrospective study of patients with heart transplantation performed during a long twenty-three year time span. Analyses are based solely on demographic, clinical, biochemical and coronary angiographic data. We did not analyse the influence of type of immunosuppression or donor-dependent factors.

\section{Conclusions}

Significant coronary stenoses are found mainly more than 5 years post heart transplantation. Most patients with significant coronary stenoses can be treated safely and effectively with percutaneous coronary intervention with contrast-induced nephropathy prophylaxis. Risk factors of coronary vasculopathy post OHT require further investigations.

\section{References}

1. Hertz MI, Aurora P, Christiae JD, et al. Scientific Registry of the International Society for Heart and Lung Transplantation: Introduction to the 2009 Annual Reports. J Heart Lung Transplant 2009; 28: 989-992. 
2. Valantine HA. Cardiac allograft vasculopathy: central role of endothelial injury leading to transplant "atheroma". Transplantation 2003; 76: 891-899.

3. Taylor DO, Stehlik J, Edwards LB, et al. Registry of the International Society for Heart and Lung Transplantation: Twenty-sixth Official Adult Heart Transplant Report - 2009. J Heart Lung Transplant 2009; 28: 1007-1022.

4. Hornick P, Smith J, Pomerance A, et al. Influence of acute rejection episodes, HLA matching and donor/recipient phenotype on the development of "early" transplant associated coronary artery disease. Circulation 1997; 96: 148-153.

5. Mehra MR, Uber PA, Uber WE, et al. Allosensitization in heart transplantation: implications and management strategies. Curr Opin Cardiol 2003; 18: 153-158.

6. Tu W, Potena L, Stepic-Biek P, et al. T-cell immunity to subclinical cytomegalovirus infections reduces cardiac allograft disease. Circulation 2006; 114: 1608-1615.

7. Mehra MR, Ventura HO, Chambers R, et al. Predictive model to assess risk for cardiac allograft vasculopathy: an intravascular ultrasound study. J Am Coll Cardiol 1995; 26: 1537-1544.

8. Johnson DE, Gao SZ, Schroeder JS, et al. The spectrum of coronary artery pathologic findings in human cardiac allografts. J Heart Transplant 1989; 8: 349-359.

9. Marenzi G, Assanelli E, Marana I, et al. N-Acetylcysteine and contrast-induced nephropathy in primary angioplasty. N Engl J Med 2006; 354: 2773-2782.|

10. Stewart S, Winters GL, Fishbein MC, et al. Revision of the 1990 working formulation for the standardization of nomenclature in the diagnosis of heart rejection. J Heart Lung Transplant 2005; 24: 1710-1720.

11. Rahmani M, Cruz RP, Granville DJ, et al. Allograft vasculopathy versus atherosclerosis. Circ Res 2006; 99: 801-815.

12. Billingham ME. Pathology of graft vascular disease after heart and heart-lung transplantation and its relationship to obliterative bronchiolitis (review). Transplant Proc 1995; 27: 2013-2016.

13. Weston MW, Spoto E Jr, Sommers E, et al. Stenting unprotected left main artery coronary artery stenosis in heart transplant patients - the good, bad, and the ugly. J Heart Transplant 2001; 20: $1228-1232$.

14. Aqel RA, Wells BJ, Hage FG, et al. Re-stenosis after drug-eluting stents in cardiac allograft vasculopathy. J Heart Lung Transplant 2008; 27: 610-615.

15. Tanaka K, Li H, Curran PJ, et al. Usefulness and safety of percutaneous coronary interventions for cardiac transplant vasculopathy. Am J Cardiol 2006; 97: 1192-1197.

16. Lekston A, Zakliczyński M, Gąsior M, et al. Comparison of longterm results of drug-eluting stent and bare metal stent implantation in heart transplant recipients with coronary artery disease. Kardiol Pol 2010; 68: 131-134.

17. Hiemann NE, Knosalla C, Welinhofer E, et al. Quilty indicates increased risk for microvasculopathy and poor survival after heart transplantation. J Heart Lung Transplant 2008; 27: 289-296.

18. Hiemann NE, Knosalla C, Welinhofer E, et al. Quilty in biopsy is associated with poor prognosis after heart transplantation. Transpl Immunol 2008; 19: 209-214. 